\title{
Contemporary Greedy Institutions: An Essay on Lewis Coser's Concept in the Era of the 'Hive Mind'
}

\author{
MARIANNE EGGER DE CAMPO* \\ Berlin School of Economics and Law
}

\begin{abstract}
Lewis Coser perennially discussed various forms and facets of 'greedy institutions' with their total grasp on the individual. Coser's 'greedy institutions' demand undivided time and loyalty from the individual who will voluntarily devote him/herself for exclusive benefits only granted to loyal followers. Although the ancient authorities have vanished-princes with their court Jews, masters with their servants, or religious and political missionaries-one can argue that the idea of the greedy institution is far from obsolete today. Management consultants, 24/7 old-age carers from Eastern Europe and particularly the 'hive mind' of new social media show that a revisiting of Coser's theory can help in understanding modern forms of greed in institutions. This awareness may enhance vigilance against intrusions into personal autonomy.
\end{abstract}

Keywords: greedy institutions, Lewis Coser, new media, 24/7 migrant carers, spin doctors, consultants, power relations

Sociologický časopis/Czech Sociological Review, 2013, Vol. 49, No. 6: 969-987

One concept that incessantly occupied Lewis Coser's as well as Rose Laub Coser's [Coser 1999] critical thinking was the allegiance claimed by the individual in relations of power. He analysed the relations between sectarians and sects as early as in the 1950s [Coser 1954], and the relation between a powerful ruler and his eunuchs [Coser 1964] or court Jews [Coser 1972]. Further, he compared celibacy in the Catholic Church with the claim for complex marriage in the utopian communities of the late 18th and the 19th century in the United States [Coser 1967]. In another bold comparison, Coser analysed the similarities between Jesuits and Leninists in terms of their relations to the collective [Coser 1973b] and (prematurely) predicted the obsolescence of the occupational role of the domestic servant [Coser 1973a]. A shared trait of these obviously very diverse phenomena is, by and large, the lack of external coercion and the unlimited claim made on all of the individual's cathectical (i.e. mental and emotional) energy.

\footnotetext{
* Direct all correspondence to: Marianne Egger de Campo, Berlin School of Economics and Law, Department of Public Administration, Alt Friedrichsfelde 60, 10315 Berlin, Germany, e-mail: marianne.egger@hwr-berlin.de.
}

C Sociologický ústav AV ČR, v.v.i., Praha 2013 
Coser contrasts this greediness of institutions that 'seek exclusive and undivided loyalty' [Coser 1974: 4] with the 'modern (urban) life style' [Coser 1974: 3] in non-totalitarian societies. His choice of historical examples of 'greedy institutions' actually does not refer to the époque of the modern individual with her Mertonian role set, but rather seems to point at a past with a lower degree of social differentiation. Coser seems to imply that in the course of modernisation, individual autonomy had to be wrested from rulers, religious collectives, and employers. ${ }^{1}$

Coser's comparison of apples to oranges indicates a deep belief in modern society (Gesellschaft as opposed to Gemeinschaft) that grants freedom and autonomy to the individual. However, individual freedom and autonomy may never be taken for granted, which shall become obvious in my following attempts to extend Coser's concept of greedy institutions to present-day phenomena: spin doctors and management consultants, 24/7 old-age carers from Eastern Europe, and particularly the 'hive mind' that is forming in social media-all of which can be fruitfully discussed in the light of the concept of greedy institutions.

Even if my empirical evidence may not always meet the standards of methodological purists, I hope to speak in the spirit of Coser, who warned that ' $[t]$ he fallacy of misplaced precision consists in believing that one can compensate for theoretical weakness by methodological strength' [Coser 1975: 692].

But let me start by briefly introducing Coser's concept of greedy institutions: Coser compiled the above-cited papers into a book in 1974, which he introduced with the observation that organised groups compete for the limited time and libidinal energies of the individual [Coser 1974: 1]. The greater the degree of differentiation in societies, the more the individual is 'enmeshed in a web of group affiliations and hence subject to the pushes and pulls of many claimants to his commitment' [Coser 1974: 2]. While modern urban society respects that each individual is faced with competing obligations for time and allegiance, the greedy institution transgresses the normative limits that protect the private life and autonomy of the individual. Modern man-or for the sake of the following example rather modern woman-has to meet different claims as an employee, as a mother, or as a member of a political movement. As difficult as this may be, it is still possible to reconcile competing obligations and moreover it is socially accepted. Labour laws limit the claims of the employer, a democratic constitution guarantees the freedom to withdraw from political activism, and the countless self-help books on work-life balance reflect the common belief that mums also have the right to relax and enjoy leisure-time activities. 'During the process of social differentiation, tensions and conflicts develop precisely where a new normative pattern for differential allocation of time and energy has not yet been estab-

\footnotetext{
${ }^{1}$ Coser's analysis of the political functions of eunuchs, who helped to overcome early forms of bureaucracy (even if not modern Western bureaucracies as they have been defined by Weber) in Byzantium and his portrait of the Bolshevists as political sectarians hint at the possible co-existence of greediness and elements of modernity in society.
} 
lished. When compulsory public education was established, for example, farmers protested that they had a right to the full-time labor of their children. Today, there is no choice in the matter of whether children should leave the home for school in the morning.' [Coser 1974: 4] Even if the German school holidays in autumn are an echo of the earlier need to harvest potatoes with the help of children's labour, nowadays families try to fill that time with recreational activities.

One of the most important safeguards of personal autonomy in modern societies is the periodic withdrawal of the individual from social interaction with and observation by others. '[The individual's] periodic insulation from [his role partners'] observability, and ... the fact that he does not interact with all of them at the same time, reduces the burden of their contradictory expectations.' [Coser 1974: 7] Generally speaking, the notion of work-life balance prescribes that we retreat for the activities of life and return to our private households and families. We eat, sleep, and enjoy 'chilling out' in our private sphere. ${ }^{2}$

Although greedy institutions clearly exercise power over the individual, they 'tend to rely on voluntary compliance and to evolve means of activating loyalty and commitment. ... Greedy Institutions aim at maximizing assent to their styles of life by appearing highly desirable to the participants.' [Coser 1974: 6] They offer exclusive benefits to their members: access to truth, insight into the course of history, or religious revelations; the honour of being among the chosen ones, the illuminated, to be a member of a cadre or the elite, and exclusive access to the powerful. At the same time, greedy institutions weaken or even sever existing social ties to relatives, friends and particularly lovers, or forbid them completely (e.g. by the rule of celibacy). The relationship between the greedy institution and the individual has to be exclusive and does not tolerate competition.

Coser illustrated his concept with the use of historic examples such as court Jews or royal mistresses, the American middle-class housewife or domestic servants, religious sects or the Bolsheviks as militant political activists. He offered a collection of patterns of undivided commitment ' ... to stimulate the search for other instances in which the perspective of this book may be expected to bear sociological fruit' [Coser 1974: 16]. I will therefore take up this invitation by exploring the validity of the concept for the relations of the individual to others in the present day.

\footnotetext{
${ }^{2}$ Erving Goffman, by contrast, coined the term 'total institution', where ' ... all aspects of life are conducted in the same place and under the same single authority' [Goffman 1961: 6]. But the total institution uses coercion and physical barriers to incarcerate inmates. The greedy institution does not need any such measures to secure sustained commitment.
} 


\section{Spin doctors and management consultants as contemporary court Jews and eunuchs}

When political rulers in absolutist states or bureaucratic empires wish to shore up their autonomous powers so as not to be dependent on feudal retainers, bureaucratic officials, gentry families, estates, or guilds of commoners, they are likely to attract to their court men who have no roots in the society over which these rulers exercise dominion. [Coser 1972: 574]

The court Jews depicted by Coser as the financiers, advisors and instruments of the Hapsburg Emperors and the German princes were typically strangers in the communities they acted in. Referring to Simmel's concept of the stranger [1908], Coser emphasised the alienation of ghetto Jews from the surrounding Christian society. ${ }^{3}$ The attractiveness of the precarious position of court Jews was the influence they gained as instruments of their rulers. Despite the ruler's dependence on the loans and advice of his court Jew, despite the confidence and the intimate relationship, '[o]ften the Jew was thrown to the wolves, hung with the misdeeds of the previous regime. Even in his fall, he served his rulers' [Coser 1972: 577].

While court Jews lacked social ties to the surrounding Christian society, the eunuchs in the classical empires of Byzantium or China were typically recruited in slave raids or were sold by peasants. They were deprived of the ability to found their own families by castration. 'Political eunuchism thrived under oriental despotism, where bureaucratic or proto-bureaucratic rule had already developed but where strong patrimonial elements were still prevalent.' [Coser 1964: 881] The Emperor who wanted 'to minimize his dependency on the bureaucracy ... required men who would owe him total allegiance.' [Coser 1964: 881] In addition to being deprived of territorial and kinship ties, the eunuch was also alienated socially as 'an object of contempt and ridicule' [ibid.]. Thus, he depended on the ruler's protection and respect and submitted himself wholly to the ruler's will. As such he was the perfect instrument of this centralising patrimonial power against the bureaucracy of the empire. Since '[b]ureaucratic administration rests on the assumption that only a segment of the officeholder's personality is involved in his bureaucratic tasks while the rest remains "free" for other involvements' [Coser 1964: 884], the total devotion of the eunuch is the perfect antidote to bureaucratic organisation.

While by no means wishing to imply a similarity with Jews as stigmatised and persecuted persons and victims of genocide, I see a present-day analogy with

\footnotetext{
${ }^{3}$ Werner Cahnman, harshly criticising Coser's description of court Jews as pariahs ('sociology with the hard work left out'), shows that European Jewish-Gentile relations were far more complex and the status of the Jewish elite far closer to that of their princes than the term 'pariah' (lowest unclean caste) implies. However, he actually confirms the appropriateness of the basic concept of the stranger, which after all is the core of Coser's argument about the court Jew's social function for the mighty ruler [cf. Cahnman et al. 1989].
} 
court Jews and eunuchs in the spin doctors who side with politicians in striving to tame the bureaucracies of public administration and political parties. But not just political rulers act as greedy institutions, so do capitalist companies: When in today's corporations management consultants and expatriate managers are hired on the market, they eventually act as aliens in their respective social fields and in this they resemble the court Jews.

Management consultants similarly 'trade in other's troubles', as Robert Jackall put it [2010: 148]. Since '[n]o one likes to deal with people in troubles ...' [ibid.: 149], top managers commission consultants to solve what they-the managers-define as problems.

They depend directly on their sponsor. who can decide to terminate a programme at any time, no matter how much money or time it has already consumed. From the perspective of employees the management consultant is an untrustworthy figure, because everything an employee tells him/her will eventually reach the top management, who hired the consultant in the first place. Top management instrumentalises consultants to justify unpopular measures or to outcompete rivals in the firm. They are dependent on each other, not the least because' ... managers need and desire the mask of objectivity to cover the capriciousness and arbitrariness of corporate life; consultants want to maintain their occupational self-image as experts. Each group fuels the other's needs and selfimages in an occupational drama where the needs of organizations get subordinated to the maintenance of professional identities.' [Jackall 2010: 153]

In the movie 'Up in the Air' (directed in 2009 by Jason Reitman), protagonist Ryan Bingham is a kind of contemporary court Jew in the service of mighty companies that have outsourced the unpleasant job of firing employees. The economic recession is the equivalent of a gold rush for Bingham's employer CTC (Career Transition Counselling), so he is constantly on business trips, laying off employees all over the country, and as a result almost all his social ties are severed. ${ }^{4}$

'Career Transition Counselling' is anything but fiction. It is a euphemistic term $^{5}$ for a booming service; according to the Wall Street Journal, the 'outplacement' business annually generates some 4 billion USD in revenue. 'Business is booming amid the recession.' [Dvorak and Lublis 2009] The nation's largest outplacement firm saw a 36\% increase in revenue in the second quarter of 2009. It costs a company between 1472 and 7518 USD per case to have its employees sacked by a professional outplacement firm and using an external firm ensures that the former employee cannot file a law suit against the company [cf. ibid.].

\footnotetext{
${ }^{4}$ Bingham tolerates this total claim on his time and libidinal energy because he collects flight miles for the extremely rare 1 million miles frequent-flyer card. Again, the victim voluntarily subjects himself to the greedy institution.

5 This term provides yet further support for Jackall's opinion that '[m]anagers' public language is, more than anything else, euphemistic' [2010: 142].
} 
Political consultants and spin doctors share the fate of eunuchs with respect to the unlimited claim their bosses have on their time and labour and the dependency of their career on their masters' success. Probably every nation's domestic politics is at some time shaken by scandals involving spin doctors or political consultants. They rise and fall with the politician whose image they help to polish in the media, whose influence they foster in the governing bureaucracies, whose power they increase within the ranks of the political parties. This can be illustrated with recent examples from German politics, such as the spin doctor of former Federal President Christian Wulff (who had to step down following corruption charges), whose demise is widely documented in the media, ${ }^{6}$ including a wiki devoted to him [Süddeutsche 2011; Wulffplag Wiki n.d.].

Powerful politicians in modern democracies at times tend to act much like Coser's historic example of despotic rulers, as is illustrated by the much discussed case of the former press officer ${ }^{7}$ of the German finance minister Wolfgang Schäuble. In 2010 he was publicly humiliated by his boss at a press conference for not having hand outs ready for journalists [TheAckergaul 2010; Offer 2010]. ${ }^{8}$

The relationships between powerful politicians and their spin doctors seem to generate enough public interest to make them the focus of plots in many popular TV shows, such as the BBC satirical series 'The Thick of It' [BBC 2005] or the Danish (also broadcast in Germany) series 'Borgen' [ARTE 2012], not to mention the US movie 'Wag The Dog' (1997).

The above-mentioned cases shall suffice to generalise Coser's theoretical proposition of the powerful ruler who as a greedy institution depends on the service of aides who are alienated from the surrounding society [cf. Yin 2003:10]. These precarious but nonetheless (for the respective consultant) attractive positions do exist in modern society; so much can safely be said, even without a full exploration of the universe of spin doctors and management consultants.

\footnotetext{
${ }^{6}$ Olaf Glaeseker was a former journalist who promoted the originally inconspicuous conservative politician Christian Wulff by helping to build Wulff's image as an honest, virtuous and sensitive politician. Glaeseker and Wulff became inseparable in the late 1990s when Wulff started his career in the state of Lower Saxony. Wulff was Federal President of Germany from 2010 to 2012 and resigned following corruption charges and scandal in the media. He dismissed Glaeseker who is now also facing corruption charges. Although observers expect Wulff will be found not guilty, his political career is nonetheless ruined. 7 Michael Offer resigned after being humiliated publicly by his boss, the mighty conservative finance minister Schäuble. This affair provoked criticism about Schäuble's temper and bossy behaviour towards his aides.

8 The many negative reactions in the media-particularly the social media-show, however, that this greediness of a ruler is no longer deemed to be justified in our society.
} 


\section{Thousands of domestic servants in Germany, Austria and Italy}

Families as greedy institutions assign the traditional servant role to domestics, who in the past were a prominent feature of bourgeois households [Coser 1974: 67]. In Wilhelminian Berlin some 22\% of all households employed domestics [Kocka 1990: 121 cit. in Schmidt 2002: 207], who were typically girls and young women from rural areas-and thus had no immediate social ties in town - and they lived under the same roof of the families that employed him, although often in very bad conditions. Often housed in a junk room and fed on their masters' left-overs, they were expected to be on duty around the clock and their masters even had the legal right to punish them physically. The relationship between master and servant rests on pre-modern ideas of dominance and ascription, and the servant's job was diffusely described as all tasks in the household deemed to be beneath the masters' dignity [Tichy 1984: 42]. While industrial workers had a workday of 10 or 11 hours, the majority of domestics in Berlin around the turn of the century worked 14 to 18 hours a day [Schmidt 2002: 215]. This long and indeterminate workday of a domestic and the nature of her living arrangements prohibited her from being able to retreat to a private life of her own in her rare free time. Fiction and factual reports both provide evidence that domestics were often victims of sexual abuse, too [Pauleweit 1993; Schmidt 2002: 218; Tichy 1984: 40-41].

Despite the fact that a domestic earned only $10 \%$ of what a female industrial worker did in Berlin around 1900 (because the largest part of their pay was in kind), ${ }^{9}$ the position was attractive since it did not require any particular qualifications, included housing (although in reality of very poor quality) and held the promise of permanent, life-time employment (although only in wealthy bourgeois households) [Schmidt 2002: 216].

Coser predicted that the tasks traditionally performed by servants would in the future only be provided on a specialised basis, and that ' $[\mathrm{f}] \mathrm{amilies}$ will no longer be able greedily to devour the personality of their servants' [Coser 1973a: 39]. Nevertheless, today we see that there are thousands of women-mostly from Eastern Europe-working as live-in carers for elderly people dependent on care in Austria, Germany, and Italy. The service they provide is called 24-hour-care ('24-h-Pflege'), and as such is very similar to the work done by domestics around the year 1900. The crucial difference is that nowadays it is no longer merely a private arrangement of exploitation, but one that is accepted and subsidised by the very welfare state in charge of undoing the effects of exploitative capitalist markets.

In Austria, where in 2012 there were approximately 433000 care dependent people, some 30000 (mostly female) carers (mostly from Slovakia) work for

\footnotetext{
${ }_{9}$ As Schmidt showed, the young female industrial workers living with their families had to contribute their wages to the household budget-so they could also only dispose of very little pocket money [Schmidt 2002: 217].
} 
a daily wage of about 40-50 EUR in the households of dependent elderly people [Prochazkova, Rupp, and Schmid 2008: 93, 158]. Since the Austrian government waged a legalisation campaign in 2008, the vast majority of these carers are self-employed and thus no labour law restrictions on working hours or salary apply. In addition, experts estimate that there are still approximately 10000 to 15000 carers working in the black market.

In Germany approximately 1.18 million care dependent people in private households opted to receive a cash benefit from state long-term care insurance to either pay a family member or hire a carer to provide long-term care [Statistisches Bundesamt 2013]. They or their families are potential employers of live-in carers, but estimates of the real number of live-in carers range from 50000 in 2005 [Bundesministerium für Familie, Frauen, Senioren und Jugend 2005: 316] to 100000 in 2009 [Neuhaus, Isfort, und Weidner 2009: 84]. Since various legal avenues to such employment exist in Germany and these are subject to legal restrictions on working hours and wages, it is harder to tell whether live-in carers work on a legal or illegal basis. There have also been various judicial rulings forbidding 'pseudo-self-employment' and standards of minimum wage and maximum working hours are geared towards making this type of work a regular, legal form of employment [Egger de Campo 2013]. However, given that foreign carers work in socially isolated conditions in families and their unfamiliarity with the local language and legal regulations leaves them in a position of dependence, we can only assume that the practice of 24/7 care in Germany results in similar labour conditions as in Austria.

The situation in Italy is similar, but much better researched: in 2004 it was found that there were 700000 so-called badant $i$ working as live-in carers and were paid a monthly wage of 700-900 EUR [Lamura et al. 2008: 53]. Their status is legal, but labour standards are violated on a regular basis, since negotiating with a greedy institution is difficult, risky and cumbersome.

In the course of legalising 24/7-care in Austria the government introduced additional subsidies of 550 EUR monthly for families with a care dependent member to hire a live-in carer, even if the care dependent person has other considerable assets [BMASK Bundesministerium für Arbeit, Soziales und Konsumentenschutz n.d.]. This means that the Austrian welfare state acts as an accomplice to the greedy institution of the family: women born around $800 \mathrm{~km}$ east of the place of their employment are legitimately paid only a fraction of the union wages paid to Austrian care workers. Furthermore, denying any social benefit to foreigners emphasises the ascriptive trait of the carers' origins in Eastern Europe and devalues their obviously needed labour. This smells suspiciously of colonialism.

Live-in carers are dependent on the family they work for, and they are socially isolated (because of their working conditions, different language, and since they often live in rural areas far from any public transportation) [Hamann 2012]. They literally work around the clock because many of their clients need assistance at night. They are attracted to this work by the income, which is far higher 
than in their home countries, where many care workers have been dismissed in the course of welfare reforms after the transformation in 1990 [ $c f$. Lamura et al. 2008]. They suffer from the separation from their own families [Hamann 2012] and are at risk of sexual abuse and becoming victims of crime [Hamann 2012; Leidenfrost 2009] - just like their predecessors a century ago. The labour relationship of carers to the greedy institution family, although initially expected to become obsolete in modern societies, has returned with the retrenchment of the welfare state; had Coser known this, he would probably have revised his prediction of 1973.

\section{The greedy 'hive mind' and the Facebook sect}

Castells regards social power in the network society as exerted by and through networks [Castells 2011]. He distinguishes four forms of power, among which networking power constitutes 'the power of the actors and organizations included in the networks ... over those human collectives or individuals not included in these global networks. This form of power operates by exclusion/inclusion'. [ibid.: 774] Thus, networks, like Coser's religious and political sects, exert power by means of inclusion or exclusion (of the unworthy) [Coser 1974: 130-131].

Facebook offers roughly one billion users a uniform role and standardised format for presenting themselves to the network and to the world at large, to socialise with other users ('friends'), and to document their views and activities on the Web. The standardised formats of social media (Facebook, blogs) reduce their users to prefabricated multiple choice profiles and encourage pseudonymous comments [cf. Lanier 2010: 16, 47-48; Lovink 2011: 186].

Uniformity is also a characteristic of members of a sect. As Coser points out, 'the sect has a tendency to level off individuality. A many sided development of the member's personality is likely to bring into play attitudes and thoughts which cannot easily be controlled'. [Coser 1974: 107]

The increasing number of reports about Facebook censoring allegedly sexual images - nursing women or women with breast cancer [Iborra 2012] —are indicative of the autocratic power regime to which users are subject. Feminists have observed at the same time that misogynous posts or images have been left online even after being reported to Facebook [Hendren 2012]. 'What seems unfair about Facebook's blocking policies is that it is almost impossible to get in touch with a live person or even defend yourself.' [ibid. 2012] The uniformity of the users and the authoritarian character of the medium complement each other because, as Coser writes, '[d]espotism thrives on uniformity' [Coser 1974: 113].

But while users could easily detect authoritarian tendencies in a religion or a government, they fail to scorn greedy institutions that are allegedly 'hip, fresh, and inventive' [Lanier 2010: 47]. Facebook countered all attempts to fend off the introduction of the 'Timeline' feature. By chronologically ordering all pictures 
and posts, the life of a single user is made even more transparent to the public. ${ }^{10}$ The same applies to the facial recognition software in Facebook, which was banned by regulators in the European Union [Sengupta and O'Brien 2012].

According to Metcalfe's Law, the value of a communication network can be expressed by the square of the number of its users, because that reflects the number of potential contacts within the network. Thus, the more members the network has, the more severe the harm suffered by not being a part of it.

Services like Klout ${ }^{11}$ calculate a score for a social media user's reputation in social networks-the Klout-Score-which reflects their alleged influence on others in virtual social networks such as Facebook or Twitter. Klout is not only used to rank celebrities like politicians or pop stars, but is also referred to when recruiting personnel for jobs in the internet economy. Klout scores can be checked by every user about any other user of social networks without prior notification of or even permission from the person concerned. Given that this score has an impact on an individual's professional career, it is obvious that, at least in the case of some people, social media greedily intrude into all of their social spheres.

The greedy institution of Facebook is attractive to users because it is so large, they submit voluntarily to 'Nerd Reductionism' [Lanier 2010] and to an unclear policy of decency, and consciously accept the risk of being ridiculed by others. Cases of Facebook users who accidently invited the whole network to a birthday party or something similar are legendary and have happened all over the world. The greedy institution of the Facebook community then claims access to the real world of these users and harasses them in their daily lives.

The heavy amount of time that users have to invest to make sure that they have no compromising images or quotes circulating on the Web indicates that here greed also simply refers to the time and energy that is detracted from other more private spheres of activity.

Ardent Facebook and microblog users that lead an 'always-on lifestyle' [Boyd 2012] represent the technological vanguard within a community that stages exclusion rituals against unworthy or unclean users. The same principle applied when sectarians were fighting heretics: 'Since the sect tends continually to produce heresy, it is understandable that sectarians will often spend considerably more time and energy on the persecution of heretics than on the pursuit of their avowed aims.' [Coser 1974: 109]

\footnotetext{
${ }^{10}$ With the breaking news about the National Security Agency's 'Prism' project (i.e. wire tapping of phone calls, Google and Facebook servers in the United States in June 2013) we may well assume that the large data collections of Facebook are also analysed by the secret service.

${ }^{11}$ See 'Klout: The Standard for Influence.' Retrieved 7 September 2012 (http://klout.com/ home).
} 


\section{No ESC(ape)}

The particular problem of the greedy institution of social media is that there is no way out of virtual social circles because the network links all available information and the data in personal profiles will remain with Facebook even after their deletion by the user [europe-v-facebook.org 2012]. In this social media resemble the utopian communities of the Shakers or of Oneida, where '[m]utual criticisms, confessions and similar forms of control helped insure that the member could not preserve even a shred of privacy in the face of the greedy community. All aspects of a man's private life were at all times accessible to public scrutiny.' [Coser 1967: 213]

This is a direct violation of the necessary condition of preserving personal autonomy in society: there is no way to withdraw periodically or to parcel information and compartmentalise socialising behaviour:

It breaks my heart when I talk to energized young people who idolize the icons of the new digital ideology, like Facebook, Twitter, Wikipedia, and free/open/Creative Commons mashups. I am always struck by the endless stress they put themselves through. They must manage their online reputations constantly, avoiding the everroaming evil eye of the hive mind, which can turn on an individual at any moment. A 'Facebook generation' young person who suddenly becomes humiliated online has no way out, for there is only one hive. [Lanier 2010: 100]

Since interactions on the Web are saved and managed by powerful machines that never forget, what we have is the phenomenon of virtual immortality: Family members of a deceased Facebook user or even just the owner of an e-mail account either have to know all the personal passwords to her/his virtual existence, or else need a lot of documentation, like translated and authenticated death certificates, etc., to be able to terminate the virtual life of their deceased relatives.

\section{The cadre, the elite and hackers}

The greedy collective of new media is dominated by a highly disciplined (in terms of work ethos) cadre of hackers, who were portrayed by Steven Levy in 1984 as 'Heroes of the Computer Revolution' [Levy 2010b]. Many of his statements suggest the missionary character of this new media elite: 'If the software world had saints, Stallman would have been beatified long ago'; ' ... Creative Commons evangelist ... '; 'Stallman is a fundamentalist, a Hutterite of hackerism' [Levy 2010a].

Sectarians claim to be in possession of the truth and although sects seem to be egalitarian in their uniformity, strong authoritarian relations structure the sectarian group: ' ... the small leadership clique can legitimize its control by refer- 
ring to its total involvement in, and greater sacrifices for the tasks of the organization' [Coser 1974: 113].

Hackers represent a technological vanguard, rebelling against authorities in the net (such as system administrators, digital rights, protection of data privacy etc.). Irrespective of their true origin - be it MIT [Levy 2010b] or the Phreakers [Coleman 2012] - they make up a cadre of the adept and illuminated and are consequently today's equivalent of the religious and revolutionary leaders of sects. Being a true hacker requires total involvement in the online community and is incompatible with withdrawal into other social roles and obligations. You have to be permanently online, immersed in writing code, 'in love with computers, myopically focused on them to the neglect of all else, living and breathing the world of computing' [Margolis and Fisher 2003] to be accepted as worthy.

Hackers are distinct from the ordinary internet or computer user because they follow a mission, which is represented by the hacker ethic. ${ }^{12}$ Their core ethics include the demand for total and unlimited access to computers, which is attached to their expectation that the availability of cheap computers would empower 'the people' to have broad access to information and consequently to the truth. As a result, hackers also disassemble and manipulate, improve and debug computers if they consider them broken. In their point of view, all information should be free, and they dogmatically believe in decentralisation. Generally the hacker ethic possesses the spirit of a technology-driven utopia, though the rules of this hacker ethic clearly conflict in many ways with societal interests. While hackers are powerful members of the greedy collective of the hive mind, their ethic is not shared by the people who are the targets of their actions; this does not necessarily bother the members of the sect, because ' ... by its exclusive structure, [it] creates a morality opposed to that of the rest of society' [Coser 1974: 104].

\section{Don't be evil—the Jesuits of new media at Google}

Google is regarded as the 'mecca of hackers', where it is expected that passion is what drives people's work [Levy 2010a]. To work for this promising internet startup, employees were required to be extraordinarily committed and to dedicate all their time and energy to the project. This commitment, however, represents more than just a cathectic investment or a desire for self-expression, since there is a clearly identifiable partner in this relation: Google. The company's permanent and enduring demands on its employees insulate them from all other social

\footnotetext{
12 This ethic although published in Levy's book on Hackers [Levy 2010b] and in a modified version on the webpages of the German Chaos Computer Club [n.d.] is necessarily established by practice since hackers tend not to formally organise themselves [Coleman 2012].
} 
spheres-a typical feature of a greedy institution. As Google's former marketing officer Douglas Edwards notes about his former colleagues:

Many of my overcaffeinated twenty-something colleagues had relocated from outside the Bay Area. They had no local friends, no attachments, no relatives, and often no TVs to distract them. They had Google.

On the off chance an employee might succumb to the allure of some idyllic 'real life', Google encased us in a cocoon of essential services-on-site haircuts, onsite car washes, on-site dentist and doctor, free massages, free snacks, free dinner, gaming groups, movie nights, wine and beer clubs, tech talks and lectures by globally recognized speakers. And everywhere you turned, intelligent companionship. If the city of Mountain View had not zoned our building non residential, many Googlers would have given up their apartments to establish a Plex Biosphere. [Edwards 2011: 85]

Young programmers can easily be lured by seemingly generous offers of free food and paid time to pursue their own pet projects. Compared with the value of their code, these benefits are just sham and hide the fact that these employees' social lives and liberties are extremely restricted.

A similarly ascetic life style is typical for the Jesuits, as Coser writes: 'The Jesuit ... is involved in an essentially instrumental activity in which all the resources of the person are systematically disciplined in the pursuit of the apostolic goal of guiding the world to God.' [Coser 1974: 120] After all, Google's motto, 'don't be evil', sounds like a religious credo, and the confessions of a young employee in a video on the company's recruitment pages insinuate something esoteric:

One of the things that really really gets me at Google is that everybody is happy ... this results in a huge synergy. You have thousands of people who are happy and who are really really interested in helping you ... so all these things they accelerate the rhythm of what happens at Google.... And the rhythm at which we can make products and at which our customers get happy and we get happy as well. [Rus 2008]

The pages with descriptions of life (and note, not just 'work'!) at Google present the company as a cheerful community, where employees can bring their dogs to work, where the organic food in the cafés is grown on the premises, and where there are slides instead of stairways [Google 2009]. Images of a Halloween party, with wild costumes, adds to the impression that this is not a workplace but a continuous children's birthday party [Google 2011].

But what looks like fun is, of course, designed to promote the productivity of the personnel. The company's paternalistic yet exploitative approach is also expressed in Larry Page's motto: 'We don't just want you to have a great job. We want you to have a great life. We provide you with everything you need to be 
productive and happy on and off the clock.' [Page n.d.] As an employer, Google seems to address a desire that Coser described back in 1974 as ' ... certain recently fashionable currents of thought that tend to deplore in a rather indiscriminate fashion the differentiated, segmented, and "alienated" character of modern life' [Coser 1974: 17]. He went on to point out that ' ... attempts to create a "wholeness" of social involvement might, if unchecked, eventuate in restrictions of individual freedom considerably more damaging to the human spirit than modern fragmentation and segmentation' [Coser 1974: 17-18].

An insensitivity to exploitative relations is common among hackers. They take pleasure in hackathons, where people spend a night programming a project [Levy 2010a]. In the Free/Open Source Software movement, people volunteer ${ }^{13}$ to write code and by doing so often fix the problems of the very companies whose customers they are. Crowdsourcing uses the brain power of passionate amateurs who help replace well-paid developers or professional photographers with the products of amateur photographers [Howe 2006]. As a typical feature of the greedy institution, the boundaries between the different social spheres and social roles are blurred, and work consequently becomes a fun leisure time activity that doesn't need to be paid for. The hive mind is greedy and it serves, in this case, the interests of the greedy capitalist companies.

Of course, not everyone who writes code and loves her/his job falls victim to a greedy collective like geek culture. But to question its one-dimensionality and its claims for total involvement leads to exclusion. A fact that accounts for male dominance in computer science: Although in North America 25\% of the Master's degrees in computer science and computer engineering and $15 \%$ of the doctorates in these fields were awarded to women in the 2004-2005 academic year [cf. Gabbert 2009: 3120], only 2\% of the contributors to Free/Open Source software projects are female [Cinco 2006 cit. in Stalder 2012: 252]. A longitudinal study of computer science students at Carnegie Mellon University reported that 'more women than men link their interest in computer science to other arenas such as medicine, the arts, space exploration, etc.' [Fisher and Margolis 2002: 80].

A popular example of crowdsourcing is the online encyclopaedia Wikipedia, which Lanier compares to the Bible. Because just as the Bible claimed to be the word of God, Wikipedia claims to reflect humanity's knowledge of the truth-or simply The Truth. Discussions and editing wars on Wikipedia show that '... Wikipedians always act out the idea that the collective is closer to the truth and the individual voice is dispensable' [Lanier 2010: 144]. This is similar to the way sectarians demand conformity and regard a dissenter as a danger to the coherence and homogeneity of the group [cf. Coser 1974: 107-108]. 'Like Wikipedia, the Bible's authorship was shared, largely anonymous, and cumulative, and the obscurity of the individual authors served to create an oracle-like ambience for the document ... But when people buy into the oracle illusion, the Bible

${ }^{13}$ Mind that the individual always submits voluntarily to greedy institutions. 
just turns into a tool to help religious leaders and politicians manipulate them.' [Lanier 2010: 46-47]

Few critics foresee the danger of a computational cloud [Lanier 2010: 47] that would constitute the culmination of Ray Kurzweil's idea of a singularity in which the brains of every single person will in the near future be united in a superior collective intelligence. For Kurzweil's followers, there seems to be nothing wrong with the claim of a greedy collective to not only contain but also to determine what is worth knowing. Hence Larry Page, an ardent fan of Ray Kurzweil's idea of this singularity [Levy 2012: 86-87], described his vision of a Google search engine that would be implanted in people's brains and would provide them with all the information they need, for instance, when they are being introduced to someone. Google would then be able to offer results if when a person doesn't know what he or she is looking for [cf. Levy 2012: 88].

Even if this sounds like science fiction, Google has long begun uploading the content of the world's books into the cloud and has begun shipping out prototypes of 'Google Glass' - a mini monitor placed in the corner of spectacles. Interestingly, few people-apart from Lanier, who refers to the idea of singularity as cybernetic totalism [Lanier 2010: 18] —seem to find this vision spooky.

\section{Conclusion}

In this essay I tried to make two points: First, there are contemporary greedy institutions in our society and we should not assume that modern society respects the competing involvements and commitments of the individual. The examples discussed in this article show that nowadays the greediness of these institutions may be harder to discern, but by focusing on the power differential the totalistic claims on all an individual's time and energy becomes obvious. We ought not to be dazzled by the voluntary nature of the relations. Second, Coser's concept of Greedy Institutions is far from obsolete. His papers dating back 40 to 50 years actually shed light on the diffuse sense of uneasiness currently caused by the new interactive internet [Koch 2010; Morozov 2011; Rühle 2010]. Most network theorists have a horizontal notion of the Web; they ignore power relations [cf., e.g., Barabási 2003; Galloway 2007] and fail to note power differentials. ${ }^{14}$ To look at the virtual communities of the Web as greedy collectives in Coser's sense is truly instructive and illuminates its potential threat to personal autonomy.

By watching for the existence of pre-modern master-servant relationships in post-colonial times we are alerted to present forms of economic colonialisation with the acceptance of welfare states paying benefits to greedy employers.

\footnotetext{
${ }^{14}$ Manuel Castells' theory of power in the network society speaks of programmers, switchers and protocols, but is so abstract that it even lacks concrete agents to whom a human being could relate [Castells 2011].
} 
The greed of capitalist companies, as they extend their grasp on their management personnel and hire consultants with unconditional allegiance, has been discussed, for example, by Sennett [1998] and Jackall [2010], but without reference to the concept of greedy institutions. And when the behaviour of the democratically elected representatives of the power of the people is subjected to critical scrutiny we find that the hustle of democratic routines tends to obfuscate the totalistic claims being made on political staff on a daily basis. ${ }^{15}$ These two points relate to each other when we realise that it is only because we regard some sociological theories and concepts as outdated that we are ignorant of the contemporary incarnations of the old threats these concepts focused on. The idea of the modern urban man and woman entitled to a private life of their own choosing is neither old fashioned nor fully realised.

MaRIANne Egger De CAMPO is professor of sociology at the Berlin School of Economics and Law. She was born in Austria and graduated from Karl-Franzens-University of Graz (Austria). Her research interests focus on political sociology, sociology of ageing and sociology of emotions. Together with Anthony Giddens and Christian Fleck she co-authored the German version of the textbook Sociology in 2009.

\section{References}

ARTE. 2012. 'Borgen—Gefährliche Seilschaften.' Borgen—Staffel 1 | Borgen, Gefährliche Seilschaften | Film | de - ARTE. Retrieved 19 May 2013 (http://www.arte.tv/de/borgen-staffel-1/4317466.html).

Barabási, Albert-László. 2003. Linked: How Everything Is Connected to Everything Else and What It Means for Business, Science, and Everyday Life. New York: Plume.

BBC. 2005. 'The Thick of It.' BBC Two-The Thick of It. Retrieved 19 May 2013 (http://www.bbc.co.uk/programmes/b006qgrd).

BMASK. 2012. 'Bundesministerium für Arbeit, Soziales und Konsumentenschutz. o. J. "Plattform für Pflegende Angehörige".' Retrieved 7 April 2012 (http://www.pflegedaheim.at/cms/pflege/faq_thema.html?channel=CH1780).

Boyd, Danah. 2012. 'Participating in the Always-On Lifestyle.' Pp. 71-76 in The Social Media Reader, edited by Michael Mandiberg. London and New York: New York University Press.

Bundesministerium für Familie, Frauen, Senioren und Jugend. 2005. Fünfter Bericht zur Lage der älteren Generation in der Bundesrepublik Deutschland. Potenziale des Alters in Wirtschaft und Gesellschaft. Der Beitrag älterer Menschen zum Zusammenhalt der Generationen. Berlin: Bundesministerium für Familie, Frauen, Senioren und Jugend.

Cahnman, W. J., J. B. Maier, J. Marcus and Zoltán Tarr. 1989. German Jewry: Its History and Sociology: Selected Essays by Werner J. Cahnman. Brunswick, NJ: Transaction Books.

${ }^{15}$ In this regard it could be fruitful to explore how elected politicians themselves are victims of greedy institutions. 
Castells, Manuel. 2011. 'Network Theory. A Network Theory of Power.' International Journal of Communication 5: 773-787. Retrieved 1 January 2013 (http://ijoc.org/ojs/index.php/ijoc/article/view/1136).

Chaos Computer Club. n.d. 'Hackerethik.' Retrieved 30 December 2012 (http://www.ccc.de/de/hackerethik).

Cinco, Cheekay. 2006. 'We Assume FOSS Benefits All Equally: But Does It Really?' genderIT.org. Retrieved 20 July 2010 (http://www.genderit.org/en/index.shtml?apc=--e-1\&x=93204).

Coleman, Gabriella E. 2012. 'Phreaks, Hackers, and Trolls: The Politics of Transgression and Spectacle.' Pp. 99-119 in The Social Media Reader, edited by Michael Mandiberg. London and New York: New York University Press.

Coser, Lewis A. 1954. 'Sects and Sectarians.' Dissent 1 (4): 360-369.

Coser, Lewis A. 1964. 'The Political Functions of Eunuchism.' American Sociological Review 29 (6): 880-885.

Coser, Lewis A. 1967. 'Greedy Organisations.' European Journal of Sociology 8 (2): 196. Retrieved 12 May 2013 (http://www.journals.cambridge.org/abstract_S000397560000151X).

Coser, Lewis A. 1972. 'The Alien as a Servant of Power: Court Jews and Christian Renegades.' American Sociological Review 37 (5): 574-581.

Coser, Lewis A. 1973a. 'Servants: The Obsolescence of an Occupational Role.' Social Forces 52: 31-40.

Coser, Lewis A. 1973b. 'The Militant Collective: Jesuits and Leninists.' Social Research 40 (1): $110-128$.

Coser, Lewis A. 1974. Greedy Institutions. Patterns of Undivided Commitment. New York: The Free Press.

Coser, Lewis A. 1975. 'Presidential Address: Two Methods in Search of a Substance.' American Sociological Review 40 (6): 691-700.

Coser, Rose Laub. 1999. 'Der gierige Charakter der Gemeinschaft.' Pp. 114-131 in Soziale Rollen und soziale Strukturen. Graz: Nausner \& Nausner.

Dvorak, Phredd and Joann S. Lublin. 2009. 'Outplacement Firms Struggle to Do Job.' Wall Street Journal, 20 August 2009. Retrieved 8 September 2012 (http://online.wsj.com/article/SB125069793645343423.html\#p).

Edwards, Douglas. 2011. I'm Feeling Lucky: The Confessions of Google Employee Number 59. Boston, MA: Houghton Mifflin Harcourt.

Egger de Campo, Marianne. 2013. Wie die 'Rhetorik der Reaktion' das österreichische Modell der Personenbetreuung rechtfertigt. Berlin: Harriet Taylor Mill-Instituts für Ökonomie und Geschlechterforschung der Hochschule für Wirtschaft und Recht Berlin.

europe-v-facebook.org. 2012. 'EUROPE versus FACEBOOK.' Retrieved 28 December 2012 (http://www.europe-v-facebook.org/DE/de.html).

Fisher, Allan and Jane Margolis. 2002. 'Unlocking the Clubhouse: the Carnegie Mellon Experience.' ACM SIGCSE Bulletin 34 (2): 79. Retrieved 3 October 2013 (http://portal.acm.org/citation.cfm?doid=543812.543836).

Gabbert, Paula. 2009. 'Why Are There So Few Female Graduate Students? How Can We Attract and Retain More?' Pp. 3120-3122 in Wiley Encyclopedia of Computer Science and Engineering, edited by Benjamin W. Wah. Hobokum, NJ: John Wiley.

Galloway, Alexander R. 2007. The Exploit: A Theory of Networks. Minneapolis, MN: University of Minnesota Press.

Goffman, Erving. 1961. Asylums. Essays on the Social Situation of Mental Patients and Other Inmates. Garden City, NY: Anchor Books.

Google. 2009. 'Life at the Googleplex.' YouTube video, 3:27. Retrieved 26 September 2011 (http://www.youtube.com/watch?v=eFeLKXbnxxg\&feature=youtu.be). 
Google. 2011. 'Mountain View Googleween: Home Video Contest Entry.' YouTube video, 3:00. Retrieved 26 September 2011

(http://www.youtube.com/watch?v=wfKZC94nsxk\&feature=youtu.be).

Hamann, Sibylle. 2012. Saubere Dienste ein Report. St. Pölten, Salzburg and Vienna: Residenz Verlag.

Hendren, Trista. 2012. 'Does Facebook Hate All Women-or Just Feminists?' Elephant Journal, 10 November 2012. Retrieved 1 January 2013 (http://www.elephantjournal. com/2012/11/does-facebook-hate-all-women-or-just-feminists/).

Howe, Jeff. 2006. 'The Rise of Crowdsourcing.' Wired, June 2006. Retrieved 29 December 2012 (http://www.wired.com/wired/archive/14.06/crowds_pr.html).

Iborra, Florencia Flores. 2012. 'Tell Me What Social Network You Use and I'll Tell You What Your Struggle Is.' GenderIT.org. Retrieved 1 January 2013 (http://www.genderit.org/articles/tell-me-what-social-network-you-use-and-ill-tellyou-what-your-struggle).

Jackall, Robert. 2010. Moral Mazes: The World of Corporate Managers. Oxford and New York: Oxford University Press.

Koch, Christoph. 2010. Ich bin dann mal offline: ein Selbstversuch; leben ohne Internet und Handy. Munich: Blanvalet.

Kocka, Jürgen. 1990. Arbeitsverhältnisse und Arbeiterexistenzen. Bonn: J. H. W. Dietz Nachfahren.

Lamura, G., M. G. Melchiorre, A. Principi, M. Lucchetti and F. Polverini. 2008. 'Les travailleurs immigrés dans le secteur de l'aide aux personnes âgées: l'exemple de l'Italie.' Retraite et societé 55 (3): 45-69.

Lanier, Jaron. 2010. You Are Not a Gadget. A Manifesto. New York: Jim Knopf.

Leidenfrost, Martin. 2009. Die Tote im Fluss: der ungeklärte Fall Denisa S. St. Pölten and Salzburg: Residenz-Verl.

Levy, Steven. 2010a. 'Geek Power: Steven Levy Revisits Tech Titans, Hackers, Idealists.' Wired, 19 April 2010. Retrieved 6 January 2013

(http://www.wired.com/magazine/2010/04/ff_hackers/2/).

Levy, Steven. 2010b. Hackers. 1st ed. Sebastopol, CA: O’Reilly Media.

Levy, Steven. 2012. Google Inside: wie Google denkt, arbeitet und unser Leben verändert. Heidelberg: mitp.

Lovink, Geert. 2011. 'Anonymität und die Krise des multiplen Selbst.' Pp. 183-198 in Generation Facebook: Über das Leben im Social Net. Bielefeld: Transcript verlag.

Margolis, Jane and Allan Fisher. 2003. Unlocking the Clubhouse. Women in Computing. Cambridge, MA: MIT Press.

Morozov, Evgeny. 2011. The Net Delusion: the Dark Side of Internet Freedom. 1st ed. New York: Public Affairs.

Neuhaus, Andrea, Michael Isfort and Frank Weidner. 2009. 'Situation und Bedarfe von Familien mit mittel- und osteu- ropäischen Haushaltshilfen.' Deutsches Institut für angewandte Pflegeforschung e.V. Retrieved 28 April 2011 (http://www.dip.de).

Offer, Michael. 2010. 'Michael Offer: Schäubles Sprecher wirft hin.' Zeit Online, 9 November 2010. Retrieved 19 May 2013 (http://www.zeit.de/politik/deutschland/2010-11/schaeuble-offer-pressekonferenz).

Page, Larry. n.d. 'Hiring Process: What to Expect-Google Students—Google.' Retrieved 8 January 2013 (http://www.google.com/intl/tr/jobs/students/sga/mba/fulltime/).

Pauleweit, Karin. 1993. Dienstmädchen um die Jahrhundertwende: im Selbstbildnis und im Spiegel der zeitgenössischen Literatur. Frankfurt am Main u.a.: Lang.

Prochazkova, Lucie, Bernhard Rupp and Tom Schmid. 2008. 'Evaluierung der 24hBetreuung. Endbericht.' Retrieved 8 January 2013 (http://www.sfs-research.at/ projekte/P66-Evaluierung-24-h-Betreuung/Bericht_neu_August.pdf). 
Rühle, Alex. 2010. Ohne Netz: mein halbes Jahr offline. 1st ed. Stuttgart: Klett-Cotta.

Rus, Silvius. 2008. 'Working at Google Mountain View-Silvius: Software Engineer.' YouTube video, 0:56. Retrieved 26 September 2011 (http://www.youtube.com/watch? $\mathrm{v}=\mathrm{tBhQxce0Zk4 \& feature=youtu.be).}$

Schmidt, Dorothea. 2002. 'Eine Welt für sich? Dienstmädchen um 1900 und die widersprüchliche Modernisierung weiblicher Erwerbsarbeit.' Pp. 204-222 in Weltmarkt Privathaushalt: bezahlte Haushaltsarbeit im globalen Wandel, Vol. 15, Forum Frauenforschung, edited by Claudia Gather, Birgit Geissler and Maria S. Rerrich. Münster: Westfälisches Dampfboot..

Sengupta, Somini and Kevin J. O'Brien. 2012. 'In Europe, Facebook Agrees to Stop Facial Recognition.' Retrieved 7 January 2013 (http://www.nytimes.com/2012/09/22/ technology / facebook-backs-down-on-face-recognition-in-europe.html?_r=0).

Sennett, Richard. 1998. The Corrosion of Character. New York and London: W. W. Norton.

Simmel, Georg. 1908. Soziologie Untersuchungen über die Formen der Vergesellschaftung. 1st ed. Berlin: Duncker \& Humblot.

Spertus, Ellen. 2009. 'Scarcity of Women in Computing.' Pp. 3114-3116 in Wiley Encyclopedia of Computer Science and Engineering, edited by Benjamin W. Wah. Hoboken, NJ: John Wiley.

Stalder, Felix. 2012. 'Between Democracy and Spectacle: The Front-End and Back-End of the Social Web.' Pp. 242-256 in The Social Media Reader, edited by Michael Mandiberg. London and New York: New York University Press.

Statistisches Bundesamt. 2013. Pflegestatistik 2011, Deutschlandergebnisse. Wiesbaden: Statistisches Bundesamt.

Süddeutsche. 2011. 'Präsidentensprecher Olaf Glaeseker-Wulffs Einflüsterer aus der Provinz.' Sueddeutsche.de. 22 December 2011. Retrieved 7 September 2012 (http://www.sueddeutsche.de/politik/praesidentensprecher-olaf-glaeseker-wulffseinfluesterer-aus-der-provinz-1.1241648).

TheAckergaul. 2010. 'Schäuble Macht Pressesprecher Fergig.' YouTube video, 3:58. Retrieved 19 May 2013 (http://youtube/Nb57By5VhGs).

Tichy, Marina. 1984. Alltag und Traum: Leben und Lektüre der Wiener Dienstmädchen um die Jahrhundertwende. Vienna: Böhlau.

Wulffplag Wiki. n.d. 'Olaf Glaeseker.' Retrieved 7 September 2012 (http://de.wulffplag.wikia.com/wiki/Das_Verh\%C3\%A4ltnis_zu_Olaf_Glaeseker).

Yin, Robert K. 2003. Case Study Research: Design and Methods. 3rd ed. Thousand Oaks, CA: Sage Publications. 